\title{
Awareness and usage of emergency contraceptive pills among working women: a hospital based survey from north India
}

\author{
Prateek Harne ${ }^{1}$, Amir Maroof Khan ${ }^{2 *}$ \\ ${ }^{1}$ MBBS Intern, University College of Medical Sciences and GTB Hospital, Delhi \\ ${ }^{2}$ Department of Community Medicine, University College of Medical Sciences and GTB Hospital, Delhi
}

Received: 16 February 2016

Accepted: 12 March 2016

*Correspondence:

Dr. Amir Maroof. Khan,

E-mail: khanamirmaroof@yahoo.com

Copyright: (C) the author(s), publisher and licensee Medip Academy. This is an open-access article distributed under the terms of the Creative Commons Attribution Non-Commercial License, which permits unrestricted non-commercial use, distribution, and reproduction in any medium, provided the original work is properly cited.

\begin{abstract}
Background: In spite of the decline observed in total fertility rate (TFR) in India during the last few decades, the unintended pregnancy rates continue to remain the same. With increasing employment levels of women, there has been an increase in the contraceptive usage rates, but evidence among the working women regarding the emergency contraceptive pills is lacking. The Objectives of the study was to assess, among the working women regarding the emergency contraceptive pills (ECP).

Methods: A cross sectional survey was conducted among the reproductive age group working women attending the obstetrics and gynecology outpatient department clinic of a private hospital in Delhi. Face to face interviews were conducted using a sem-structured questionnaire.

Results: Out of the 206 participants studied, around one-third (35.0\%) were not aware about ECPs. Amongst the aware, $81.3 \%$ and $44.8 \%$ did not know about the correct indication and correct timing of ECP use respectively. Amongst those who were aware about ECPs, 91.8\% had never used it.

Conclusions: Even though the awareness about ECPs is not low, the correct knowledge about its indications and correct timing is poor. More emphasis on increasing the awareness about ECPs is required to increase its correct use thereby reducing TFR further.
\end{abstract}

Keywords: Family planning, Emergency contraceptive pills, Contraception

\section{INTRODUCTION}

The total fertility rate has declined from 3.39 in 1992-93 to 2.68 in $2005-06$, but the prevalence of unintended pregnancy has remained stagnant over the same period. ${ }^{1}$ Every fourth pregnancy in India resulting in live birth is mistimed or unplanned ${ }^{1}$. Despite the 'cafeteria approach' of Reproductive and Child Health programme in India with the availability of a range of contraceptives to suit the different requirements of different couples, numbers of unwanted pregnancies is still very high. ${ }^{2}$ Unwanted pregnancies in the background of increasing population contribute to unsafe abortions, increased maternal mortality and unplanned births. ${ }^{3}$ In order to decrease TFR further, it is important to control the unintended pregnancies and one of the effective methods when others fail is emergency contraception. ${ }^{4}$ Emergency contraception serves as a backup in case regular contraception fails, thus preventing the unsafe abortions in the process. Educated and employed women are relatively more empowered and have the potential to deal with this issue of unplanned pregnancies. There is a gap in research related to emergency contraceptive pills (ECP), its awareness and usage among working women, in India.

Thus, the present study was conducted with the primary objective to assess the awareness, knowledge and usage 
of emergency contraceptive pills among the working women and its associated socio-demographic factors. The secondary objective of the study was to assess the awareness and usage pattern of contraceptive methods other than ECPs.

\section{METHODS}

A cross sectional study was conducted among the working women attending the Obstetrics and Gynecology outpatient clinics of a private hospital in the North West district of Delhi. The duration of data collection was two months, June-July 2014.

\section{Inclusion criteria}

Reproductive age group women, working in the organized sector were included.

\section{Exclusion criteria}

Subjects with apparent and gross physical or mental disorders or in an emergency condition, where it was not possible to elicit the information required, were excluded

\section{Sample size estimation}

Considering the estimated prevalence of awareness about emergency contraception among married working women to be $87 \%$ and an absolute error of $5 \%$ for $95 \%$ confidence, the sample size came out to be 174 (Epi Info for windows ver 3.4$)^{5}$

The sample size was rounded to 200 .

Sampling technique employed was consecutive type and the data was collected over a total period of 8 weeks (two days per week).

The education and occupation of the working women were classified by using the categories given in the Kuppuswamy Scale. ${ }^{6}$

The working women included in the study were interviewed by the first author on the basis of a pretested and semi structured questionnaire. The questionnaire included socio-economic particulars of the respondent such as education, employment and economic status, information on the level of awareness about emergency contraceptive pills and its usage pattern. Awareness and usage pattern of other contraceptive methods were also assessed. The females were counseled after the interview regarding the emergency contraception methods. The definition of emergency contraception used for the purpose of this study was: Emergency contraception, or post-coital contraception, refers to methods of contraception that can be used to prevent pregnancy in the first few days after intercourse. It is intended for emergency use following unprotected intercourse, contraceptive failure or misuse (such as forgotten pills or torn condoms), rape or coerced sex. ${ }^{7}$
The respondents who had at least 'heard' about emergency contraceptive pills were labelled as being 'aware' for the purpose of this study.

\section{Statistical analysis}

Data were entered in a MS Excel spread sheet and was analysed using SPSSver20. Summary statistics was calculated like means and standard deviations for numerical variables and proportions for categorical variables. Chi-square test was employed for comparing proportions. A p value of less than 0.05 was considered as statistically significant.

\section{Ethical considerations}

The study was approved by Jaipur Golden Hospital Ethics Committee. The interview was conducted in privacy, and confidentiality of the data was maintained. Verbal informed consent was obtained from all the study subjects. The Principles of Helsinki Declaration on Ethics has been followed in the present study. If any misconception regarding contraceptive methods was found, the women were given health education regarding contraceptive methods by the first author at the completion of the interview.

\section{RESULTS}

Table 1: Socio-demographic characteristics of the respondents $(\mathrm{n}=206)$.

\begin{tabular}{|c|c|c|}
\hline \multicolumn{3}{|c|}{ Socio-economic characteristic } \\
\hline & Number & Percentage \\
\hline \multicolumn{3}{|c|}{ Type of outpatient clinics enrolled in } \\
\hline Private & 130 & 63.1 \\
\hline General & 76 & 36.9 \\
\hline \multicolumn{3}{|l|}{ Religion } \\
\hline Hindu & 170 & 82.5 \\
\hline Muslim & 36 & 17.5 \\
\hline \multicolumn{3}{|l|}{ Caste } \\
\hline General & 185 & 89.8 \\
\hline OBC & 21 & 10.2 \\
\hline \multicolumn{3}{|l|}{ Sector of employment } \\
\hline Private & 151 & 73.3 \\
\hline Public & 55 & 26.7 \\
\hline \multicolumn{3}{|l|}{ Marital status } \\
\hline Married & 138 & 67 \\
\hline Unmarried & 68 & 33 \\
\hline \multicolumn{3}{|l|}{ Type of family } \\
\hline Nuclear & 124 & 60.2 \\
\hline Joint & 82 & 39.8 \\
\hline \multicolumn{3}{|l|}{ Education of husband* } \\
\hline Profession or honours & 8 & 3.9 \\
\hline Graduate or post graduate & 130 & 63.1 \\
\hline \multicolumn{3}{|l|}{ Occupation of husband* } \\
\hline Profession & 76 & 55.1 \\
\hline Semi-profession & 35 & 25.4 \\
\hline Clerical, shop owner & 27 & 19.5 \\
\hline
\end{tabular}


Two hundred and six working women attending Obstetrics and Gynecology outpatient departments were studied to find out the awareness, knowledge and usage pattern of emergency contraception. The mean (SD) age of the respondents was 27.7 (3.36) years ranging from 22 to 36 years. Nearly $2 / 3^{\text {rd }}$ were married and all the respondents were educated at least upto graduate level. The average (SD) monthly income of the respondents was Indian National Rupee (INR) 29014 (7881). All the respondents were involved in professional or semiprofessional types of jobs (Table 1).

Table 2: Association of awareness about Emergency contraceptive pills with certain socio-demographic factors.

\begin{tabular}{|c|c|c|c|c|}
\hline $\begin{array}{l}\text { Socio- } \\
\text { demographic } \\
\text { Factor }\end{array}$ & $\begin{array}{l}\text { Aware } \\
(\%) \\
n=134\end{array}$ & $\begin{array}{l}\text { Not } \\
\text { aware } \\
(\%) \\
n=72\end{array}$ & P value & $\begin{array}{l}\text { Chi } \\
\text { Square } \\
\text { value, } \\
\text { d.f. }\end{array}$ \\
\hline \multicolumn{5}{|c|}{ Outpatient clinic } \\
\hline Private & $\begin{array}{l}97 \\
(74.6)\end{array}$ & $\begin{array}{l}33 \\
(25.4)\end{array}$ & \multirow{2}{*}{$<0.001 *$} & \multirow{2}{*}{$14.185,1$} \\
\hline General & $\begin{array}{l}37 \\
(48.7)\end{array}$ & $\begin{array}{l}39 \\
(51.3)\end{array}$ & & \\
\hline \multicolumn{5}{|c|}{ Education status } \\
\hline $\begin{array}{l}\text { Profession } \\
\text { or honours }\end{array}$ & $\begin{array}{l}8 \\
(100)\end{array}$ & $0(0)$ & \multirow[b]{2}{*}{$0.030 *$} & \multirow[b]{2}{*}{$4.472,1$} \\
\hline $\begin{array}{l}\text { Graduate } \\
\text { or post } \\
\text { graduate }\end{array}$ & $\begin{array}{l}126 \\
(63.6)\end{array}$ & $\begin{array}{l}72 \\
(36.4)\end{array}$ & & \\
\hline \multicolumn{5}{|c|}{ Occupation of the respondent } \\
\hline Profession & $\begin{array}{l}89 \\
(85.6)\end{array}$ & $\begin{array}{l}15 \\
(14.4)\end{array}$ & \multirow{2}{*}{$<0.001 *$} & \multirow{2}{*}{$38.932,1$} \\
\hline $\begin{array}{l}\text { Semi- } \\
\text { profession }\end{array}$ & $\begin{array}{l}45 \\
(44.1)\end{array}$ & $\begin{array}{l}57 \\
(55.9)\end{array}$ & & \\
\hline \multicolumn{5}{|c|}{ Sector of employment } \\
\hline Private & $\begin{array}{l}115 \\
(76.2)\end{array}$ & $\begin{array}{l}36 \\
(23.8)\end{array}$ & \multirow{2}{*}{$<0.001^{*}$} & \multirow{2}{*}{$30.707,1$} \\
\hline Public & $\begin{array}{l}19 \\
(34.5)\end{array}$ & $\begin{array}{l}36 \\
(65.5)\end{array}$ & & \\
\hline \multicolumn{5}{|c|}{ Marriage status } \\
\hline Married & $\begin{array}{l}88 \\
(63.8)\end{array}$ & $\begin{array}{l}50 \\
(36.2)\end{array}$ & \multirow{2}{*}{0.643} & \multirow{2}{*}{$0.301,1$} \\
\hline Unmarried & $\begin{array}{l}46 \\
(67.6)\end{array}$ & $\begin{array}{l}22 \\
(32.4)\end{array}$ & & \\
\hline \multicolumn{5}{|l|}{ Type of family } \\
\hline Nuclear & $\begin{array}{l}89 \\
(71.8)\end{array}$ & $\begin{array}{l}35 \\
(28.2)\end{array}$ & \multirow{2}{*}{$0.017 *$} & \multirow{2}{*}{$6.198,1$} \\
\hline Joint & $\begin{array}{l}45 \\
(54.9)\end{array}$ & $\begin{array}{l}37 \\
(45.1)\end{array}$ & & \\
\hline
\end{tabular}

*Significant at $\mathrm{p}<0.05$

\section{Awareness about ECPs}

Around one-third $(35.0 \%)$ of the respondents were not aware about ECPs. The association of awareness about
ECPs with certain socio-demographic factors is shown in Table 2.

Table 3: Misconceptions about ECPs among ECPaware subjects.

\begin{tabular}{|ll|}
\hline $\begin{array}{l}\text { Misconceptions/ } \\
\text { Parameters }\end{array}$ & $\begin{array}{l}\text { ECP A ware subjects (\%) } \\
(\mathbf{n}=134)\end{array}$ \\
\hline $\begin{array}{l}\text { Did not know of ECP as } \\
\text { a method for preventing } \\
\text { pregnancy after } \\
\text { unprotected intercourse }\end{array}$ & $109(81.3)$ \\
\hline $\begin{array}{l}\text { Unaware about the } \\
\text { correct timing of } \\
\text { consumption of ECP }\end{array}$ & $60(44.8)$ \\
\hline $\begin{array}{l}\text { Considered ECP as a } \\
\text { regular tool of } \\
\text { contraception }\end{array}$ & $37(27.6)$ \\
\hline
\end{tabular}

In all, $12(5.82 \%)$ respondents had a history of spontaneous abortion. A higher proportion of the ECP unaware respondents $(8.3 \%, 6 / 72)$ reported as having suffered an abortion as compared to the ECP aware respondents $(4.4 \%, 6 / 134)$ but this difference was not significant (Chi square $=1.269$, d.f. $=1, p=0.260)$.

The reasons given by the ECP aware subjects for never having used ECP $(n=195)$ were fear of side effects (76.9\%) and didn't know about its availability $(4.5 \%)$ whereas $10.4 \%$ didn't have any specific reason.

Table 4: Awareness and usage pattern of contraceptive methods other than ECPs.

\begin{tabular}{|c|c|c|c|}
\hline $\begin{array}{l}\text { Contraceptive } \\
\text { method }\end{array}$ & $\begin{array}{l}\text { Aware n } \\
(\%) *\end{array}$ & $\begin{array}{l}\text { Ever } \\
\text { used } \\
\mathbf{N}(\%) *\end{array}$ & $\begin{array}{l}\text { Ever } \\
\text { usage } \\
\text { rate } \\
\text { among } \\
\text { aware } \\
\text { subjects } \\
(\%)\end{array}$ \\
\hline IUDs & $206(100.0)$ & $32(15.5)$ & 15.5 \\
\hline OCPs & $206(100.0)$ & $64(31.0)$ & 31.1 \\
\hline Condoms & $206(100.0)$ & $183(88.8)$ & 88.8 \\
\hline $\begin{array}{l}\text { Withdrawal } \\
\text { method }\end{array}$ & $194(94.1)$ & $181(87.8)$ & 93.2 \\
\hline Tubal ligation & $153(74.2)$ & $0(0.0)$ & 0.0 \\
\hline Vasectomy & $93(45.1)$ & $0(0.0)$ & 0.0 \\
\hline Diaphragm & 74 (35.9) & $28(13.5)$ & 37.8 \\
\hline
\end{tabular}

Among the ECP aware subjects $(n=134), 92$ reported irregular menstrual bleeding and 1 reported pelvic pain and 21 reported both of the above as the side effect of ECPs.

Electronic and print media was the source of information of ECPs among $111(82.8 \%)$ ECP aware respondents 
$(n=134)$ and doctors and other health care providers amongst the rest i.e., $17(12.7 \%)$ respondents.

Around one-fifth (21.3\%) had never used any contraception.
Among the unmarried respondents $(n=68), 53(77.9 \%)$ were reported as being sexually active. The contraceptive methods used by the sexually active respondents during their last sexual encounter were condoms $48(70.5 \%)$, OCP $3(0.04 \%)$, IUD $2(0.02 \%)$, and $15(22.0 \%)$ reported not having used any method.

Table 5: Awareness and usage pattern of contraceptives other than ECPs among married and unmarried sexually active women.

\begin{tabular}{|c|c|c|c|c|c|c|}
\hline \multirow[t]{2}{*}{$\begin{array}{l}\text { Contraceptive } \\
\text { method }\end{array}$} & \multicolumn{2}{|c|}{$\begin{array}{l}\text { Married Women } \\
(\mathbf{n}=138)\end{array}$} & \multicolumn{2}{|c|}{$\begin{array}{l}\text { Unmarried Sexually Active } \\
\text { Women }(n=53)\end{array}$} & \multicolumn{2}{|l|}{$\begin{array}{l}\text { Total } \\
(\mathrm{n}=191)\end{array}$} \\
\hline & Aware n (\%) & $\begin{array}{l}\text { Ever usage } \\
\text { rate } \mathrm{n}(\%)\end{array}$ & Aware n (\%) & $\begin{array}{l}\text { Ever usage } \\
\text { rate } \mathrm{n}(\%)\end{array}$ & Aware n (\%) & $\begin{array}{l}\text { Ever usage } \\
\text { rate } \mathrm{n}(\%)\end{array}$ \\
\hline IUDs & $138(100.0)$ & $32(23.1)$ & $53(100.0)$ & $0(0.0)$ & $191(100.0)$ & $32(16.8)$ \\
\hline OCPs & $138(100.0)$ & $59(42.7)$ & $53(100.0)$ & $5(9.4)$ & $191(100.0)$ & $64(33.5)$ \\
\hline Condoms & $138(100.0)$ & $138(100.0)$ & $53(100.0)$ & $45(84.9)$ & $191(100.0)$ & $183(95.8)$ \\
\hline $\begin{array}{l}\text { Withdrawal } \\
\text { method }\end{array}$ & 137 (99.2) & $136(98.5)$ & $43(81.1)$ & $42(79.2)$ & $180(94.2)$ & $178(93.2)$ \\
\hline Tubal ligation & $113(81.8)$ & $0(0.0)$ & $34(64.1)$ & $0(0.0)$ & $147(77.0)$ & $0(0.0)$ \\
\hline Vasectomy & $53(38.4)$ & $0(0.0)$ & $32(60.3)$ & $0(0.0)$ & $85(44.5)$ & $0(0.0)$ \\
\hline Diaphragm & $53(38.4)$ & $28(20.2)$ & $19(35.8)$ & $0(0.0)$ & $72(37.7)$ & $28(14.7)$ \\
\hline
\end{tabular}

IUD - Intrauterine device; OCP - Oral contraceptive pills

\section{DISCUSSION}

About one-third of the respondents were not aware about ECPs and a majority (91.8\%) had never used it. Takkar N et al. have reported that only around one tenth of the women studied were aware about ECPs and only $1.1 \%$ had ever used emergency contraception. ${ }^{8}$ As this study was done around a decade back, it means that there has been an increase in the awareness about ECPs over this time period. Another study by Kose V et al from rural hospital in Nagpur reported a lower proportion of women participants being aware about ECPs as compared to our study. Even the ECP usage rate was lower than the present study. ${ }^{9}$ This difference may be because of the rural urban difference in the awareness about ECPs in India. Another study from Kanpur, a district in Northern India and a study from South India have also reported very low level of awareness about ECPs as compared to that in our study. ${ }^{10,11}$

Even amongst those who have heard of ECPs, a majority did not know about its indications, method of use and side effects. This is a serious hindrance to the correct, timely and effective use of ECPs. Even making an informed decision about ECPs is not possible with a poor knowledge about its various dimensions. The ECP awareness levels were not influenced by the marital status in the present study, indicating that the reach of the term ECPs in both the groups is similar.

Through the study it was seen that the status of awareness of ECPs was affected by certain socio-demographic parameters like the type of outpatient clinic the subject visited, education status, occupation of the respondent, sector of employment and type of family of the respondent.

In our study, the respondents attending private OPD were more aware about emergency contraception than those attending general OPD. This is probably because of higher socio-economic status and greater exposure to sources of information of emergency contraception like print and electronic media. Also, those employed in the private sector were more aware than those employed in the public sector. In our study, respondents educated up to profession or honors level were more aware than those educated up to graduate level. This implied that with increasing levels of education, the awareness about emergency contraception increased.

Another study has reported that the awareness about emergency contraception increased linearly with educational level, which was a similar finding in our study. $^{12}$

Respondents belonging to nuclear family were more aware about ECP than those belonging to a joint family. In the joint family, there are higher chances of getting information about family planning from some elderly women of the house, particularly the mother-in-law. This coming from the earlier generation may not be in sync with the current availability and understanding of the contraceptives. 
The source of information about emergency contraception was mostly derived from print and electronic media, followed by doctors and health personnel. Even though another study had reported that electronic media effect of this was higher in our study as compared to the other one. ${ }^{8}$ In another study, mass media was the major source of information of emergency contraception which was similar to our study. ${ }^{10}$

Among other contraceptive methods, withdrawal method was the commonest in the present study. This method has a high failure rate. It's surprising to find such a high usage rate for this method among the working women in the present study. It strengthens the case for the need of increasing the awareness and correct knowledge about contraceptive methods in the community. The pattern of awareness levels for various contraceptives other than ECPs was similar between the married and the sexually active unmarried women. However the ever usage rate of IUDs and OCPs were higher among the married women as compared to the unmarried women. The usage rate of all sorts of contraceptives is higher among the married women than among the unmarried sexually active women. This trend highlights the need for ECP and other contraceptive methods to be promoted among unmarried and sexually active women.

The results of the study should be generalized with caution as it is a single hospital based.

\section{CONCLUSION}

The awareness about ECPs was high but the knowledge about its indications and timing of usage was poor. Among those who were aware about ECPs, it's ever usage rate was very low. This shows that even among the working and educated women, proper knowledge and usage rate of ECPs is low. Efforts should be made to increase the awareness and knowledge regarding ECPs to reduce the unplanned births, thus further reducing TFR.

Funding: Not required

Conflict of interest: None declared

Ethical approval: The study was approved by the Institutional Ethics Committee

\section{REFERENCES}

1. Dixit P, Ram F, Dwivedi LK. Determinants of unwanted pregnancies in India using matched casecontrol design. BMC Pregnancy Childbirth. 2012;12:84. doi: 10.1186/1471-2393-12-84.

2. Pachauri S. Priority strategies for India's family planning programme. Indian $\mathrm{J}$ Med Res. 2014;140(Suppl 1):S137-46.

3. Haddad LB, Nour NM. Unsafe Abortion: Unnecessary Maternal Mortality. Rev Obstet Gynecol. 2009; 2(2):122-6.

4. Trussell J, Stewart F, Guest F, Hatcher RA. Emergency Contraceptive Pills: A Simple Proposal to Reduce Unintended Pregnancies. Family Planning Perspectives. 1992;24(6):269-73.

5. Purohit N, Mathur R, Bakhshi P. Knowledge and use of emergency contraceptive pill: An analysis of perception and practice among unmarried urban women. J Family Med Prim Care. 2013;2:376-80.

6. Kuppuswamy B. Manual of Socioeconomic scale (Urban), New Delhi, Manasayan, 32, Netaji Subhash Marg, 1981.

7. World Health Organization, Fact sheet No. 244, July 2012. Available from http://www.who.int/mediacentre/factsheets/fs244/en. Accessed 11 September 2015.

8. Takkar N, Goel P, Saha PK, Dua D. Contraceptive practices and awareness of emergency contraception in educated working women. Indian $\mathrm{J}$ Med Sci. 2005;59(4):143-9.

9. Kose V, Joshi S. Knowledge of Emergency Contraception among Married Women of Reproductive Age in a Rural-based Teaching Hospital of Nagpur, Maharashtra, India. JSAFOG. 2012;4(2):106-9.

10. Kaushal SK, Saxena SC, Srivastava VK, Gupta SC, Nigam S. KAP study on contraceptive methods in Kanpur district of UP. Indian J Commun Health. 2009-2010;21(2):33-8.

11. Biradar SM. A Survey of Knowledge and Perceptions towards Emergency Contraceptives Among Working Women of Bijapur, South India. Int J Pharm Bio Sci. 2013;4(1):583-7.

12. George J, Turner J, Cooke E, Hennessy E, Savage W, Julian P, Cochrane R. Women's knowledge of emergency contraception. $\mathrm{Br} \mathrm{J}$ Gen Prac. 1994;44(387):451-4.

Cite this article as: Harne $\mathrm{P}$, Khan AM. Awareness and usage of emergency contraceptive pills among working women: a hospital based survey from north India. Int J Reprod Contracept Obstet Gynecol 2016;5:1202-6. 